Article

\title{
Leaf Age-Dependent Photosystem II Photochemistry and Oxidative Stress Responses to Drought Stress in Arabidopsis thaliana Are Modulated by Flavonoid Accumulation
}

\author{
Ilektra Sperdouli ${ }^{1,2}$, Julietta Moustaka ${ }^{1,3}$, Georgia Ouzounidou ${ }^{4}$ and Michael Moustakas ${ }^{1, *(D)}$ \\ 1 Department of Botany, Aristotle University of Thessaloniki, 54124 Thessaloniki, Greece; \\ ilektras@bio.auth.gr (I.S.); moustaka@plen.ku.dk (J.M.) \\ 2 Institute of Plant Breeding and Genetic Resources, Hellenic Agricultural \\ Organization-Demeter (ELGO-Dimitra), Thermi, 57001 Thessaloniki, Greece \\ 3 Department of Plant and Environmental Sciences, University of Copenhagen, Thorvaldsensvej 40, \\ 1871 Frederiksberg, Denmark \\ 4 Institute of Food Technology, Hellenic Agricultural Organization-Demeter (ELGO-Dimitra), \\ 1S. Venizelou Str., 14123 Lycovrissi, Greece; geouz@nagref.gr \\ * Correspondence: moustak@bio.auth.gr
}

\section{check for} updates

Citation: Sperdouli, I.; Moustaka, J.; Ouzounidou, G.; Moustakas, M. Leaf Age-Dependent Photosystem II Photochemistry and Oxidative Stress Responses to Drought Stress in Arabidopsis thaliana Are Modulated by Flavonoid Accumulation. Molecules 2021, 26, 4157. https://doi.org/ $10.3390 /$ molecules 26144157

Academic Editors: Scott Reed and Rui Fausto

Received: 9 June 2021

Accepted: 6 July 2021

Published: 8 July 2021

Publisher's Note: MDPI stays neutral with regard to jurisdictional claims in published maps and institutional affiliations.

Copyright: (c) 2021 by the authors. Licensee MDPI, Basel, Switzerland. This article is an open access article distributed under the terms and conditions of the Creative Commons Attribution (CC BY) license (https:/ / creativecommons.org/licenses/by/ $4.0 /)$.

\begin{abstract}
We investigated flavonoid accumulation and lipid peroxidation in young leaves (YL) and mature leaves (ML) of Arabidopsis thaliana plants, whose watering stopped $24 \mathrm{~h}$ before sampling, characterized as onset of drought stress (OnDS), six days before sampling, characterized as mild drought stress (MiDS), and ten days before sampling, characterized as moderate drought stress (MoDS). The response to drought stress (DS) of photosystem II (PSII) photochemistry, in both leaf types, was evaluated by estimating the allocation of absorbed light to photochemistry $\left(\Phi_{P S I I}\right)$, to heat dissipation by regulated non-photochemical energy loss $\left(\Phi_{N P Q}\right)$ and to non-regulated energy dissipated in PSII $\left(\Phi_{N O}\right)$. Young leaves were better protected at MoDS than ML leaves, by having higher concentration of flavonoids that promote acclimation of YL PSII photochemistry to MoDS, showing lower lipid peroxidation and excitation pressure $\left(1-\mathrm{q}_{p}\right)$. Young leaves at MoDS possessed lower $1-q_{p}$ values and lower excess excitation energy (EXC), not only compared to MoDS ML, but even to MiDS YL. They also possessed a higher capacity to maintain low $\Phi_{N O}$, suggesting a lower singlet oxygen $\left({ }^{1} \mathrm{O}_{2}\right)$ generation. Our results highlight that leaves of different developmental stage may display different responses to DS, due to differential accumulation of metabolites, and imply that PSII photochemistry in Arabidopsis thaliana may not show a dose dependent DS response.
\end{abstract}

Keywords: acclimation; non-photochemical quenching (NPQ); mild drought stress; moderate drought stress; young leaves; mature leaves; lipid peroxidation; singlet oxygen $\left({ }^{1} \mathrm{O}_{2}\right)$; lipid peroxidation; reactive oxygen species (ROS)

\section{Introduction}

Drought is a major limiting factor for plant growth and crop productivity [1,2] and is expected to increase in intensity, frequency and duration as a consequence of climate change [3-5]. Drought stress (DS) accelerates leaf senescence [6,7] and impairs osmotic adjustment of plants and plants' photosynthetic rate and growth $[6,8]$, thus reducing plant productivity that affects food security [4,9]. Indeed, even a short-term DS results in crucial annual losses of crop yields, preventing sustainable agriculture [5]. Consequently, an understanding of DS in relation to plant growth and development is of importance for sustainable agriculture [10].

Plants use multiple strategies to either avoid or tolerate drought stress [7]. Drought tolerance is associated with maintenance of plant water status through osmotic adjustment by the accumulation of osmoprotective substances in leaves, such as soluble sugars and proline, that help the plants to maintain leaf water status [11-15] and to acclimate to DS [14,16]. 
Drought stress can appear in an extensive range, from mild drought stress (MiDS), to moderate drought stress (MoDS), to severe drought stress (SDS), during which plants experience dehydration and wilting, finally leading to their death [17]. Several earlier studies have concentrated on SDS, though, MoDS is appearing more often in real field conditions [17]. More recent studies have demonstrated that plants apply different strategies to cope with MiDS, compared to MoDS or to SDS [10,18-20]. For example, between SDS and MiDS, only one third of differentially expressed genes overlap in Arabidopsis young leaves (YL) [20], while photosynthetic efficiency is better under MoDS than under MiDS, in Arabidopsis YL [21,22], and plants that were described to be tolerant to SDS did not perform better under MiDS [18]. Exploring the molecular and physiological strategies that plants apply to cope with MiDS or MoDS is therefore essential to ensure our future agricultural productivity [17].

Photosynthetic ability is very essential, as it directly contributes to plant growth and productivity under DS $[15,23]$. Dealing with the negative effects of DS on growth and productivity will demand to evaluate the way it impacts photosynthesis and to understand plants' responses properly, thus leaf photosynthesis analysis remains pivotal [4]. Additionally, it is well-defined that plants practice multiple stress situations that act together under natural field conditions and, in the case of DS, there is at least the need to consider the interaction with the light conditions [4,24].

Plants must retain a balance between the capture of light energy, its supply to the reaction centers, the production of NADPH and ATP and the utilization of these products for $\mathrm{CO}_{2}$ fixation and biosynthesis [25-27]. Plants, in response to DS, close their stomata to decrease water loss, which results in lower $\mathrm{CO}_{2}$ entry into the leaf and lower $\mathrm{CO}_{2}$ fixation, thus in lower need for NADPH and ATP $[28,29]$. In some cases, under MiDS and low light (LL) conditions, photosynthetic activity and, particularly, electron transport rate (ETR) and $\mathrm{NADP}^{+}$reduction are preserved, but under high light (HL) conditions, an imbalance between light energy capture and photochemical energy use appears, leading to a decrease in ETR, which leads to a high level of energy dissipation as heat to prevent the formation of reactive oxygen species (ROS) [29-31]. Consequently, under DS the absorbed light energy exceeds what it can be used and, thus, it can damage the photosynthetic apparatus, with photosystem II (PSII) being particularly exposed to damage [13,32-35]. The light-harvesting, excitation transfer, charge separation and electron transfer in PSII are the essential reactions of photosynthesis and, consequently, principally regulate its total efficiency [36]. In general, overexcitation of PSII is prevented largely by dissipation of excess excitation energy as heat, a process that is called non-photochemical exciton quenching (NPQ), and is typically measured by chlorophyll $a$ fluorescence quenching [37-39]. If this excess excitation energy is not quenched by NPQ, increased production of ROS occurs that can lead to oxidative stress and lipid peroxidation [37,40,41]. Lipid peroxidation can be assessed by malondialdehyde (MDA), that is widely recognized as a marker of oxidative stress [42-44].

Flavonoids are representative plant secondary products with at least 54 different molecules in the model plant Arabidopsis thaliana (35 flavonols, 11 anthocyanins and 8 proanthocyanidins) [45]. Flavonoids, as well as many other plant polyphenols, possess a chemical structure ideal for free radical scavenging $[45,46]$. Their antioxidant properties include reactivity to a variety of ROS [47-52], as well as metal chelating [53,54]. Drought stress enhances flavonoid accumulation [55,56], which, in turn, improves antioxidant capacity by reducing ROS and improving drought tolerance [57-59].

Responses to DS of Arabidopsis thaliana have commonly been studied in the Columbia accession, which is mainly used in plant research [17]. However, the reactions to DS are complicated and our understanding of the responses that contribute to sustaining plant growth and development during mild drought stress (MiDS), or moderate drought stress (MoDS), is incomplete $[17,20]$. 
Despite several investigates implicating flavonoids in plant drought responses, how the regulation of stress tolerance is related to leaf development stage is largely unknown. To address this issue, we investigated how flavonoid accumulation and lipid peroxidation are influenced in young and mature Arabidopsis thaliana leaves, under MiDS and MoDS, and how flavonoid accumulation modulates oxidative stress influencing PSII photochemistry in both leaf types in response to DS.

\section{Results}

\subsection{Soil and Leaf Water Status under Drought Stress}

Water deficit stress was induced gradually by withholding water [21] in a randomized block design with three different watering regimes, as follows: at the onset of drought stress (OnDS, watering stopped $24 \mathrm{~h}$ before sampling), soil water status, indicating the level of soil water stress, was $95-96 \%$ of soil capacity, at mild drought stress (MiDS, watering stopped six days before sampling), the soil water status was $66-68 \%$ of soil capacity and at moderate drought stress (MoDS, watering stopped ten days before sampling) the soil water status was $50-52 \%$ of soil capacity [22].

Leaf water status did not differ between mature leaves (ML) and young leaves $(\mathrm{YL})$ at the OnDS (Figure 1a), but at MiDS and MoDS, YL retained significantly higher leaf water content than ML (Figure 1a).

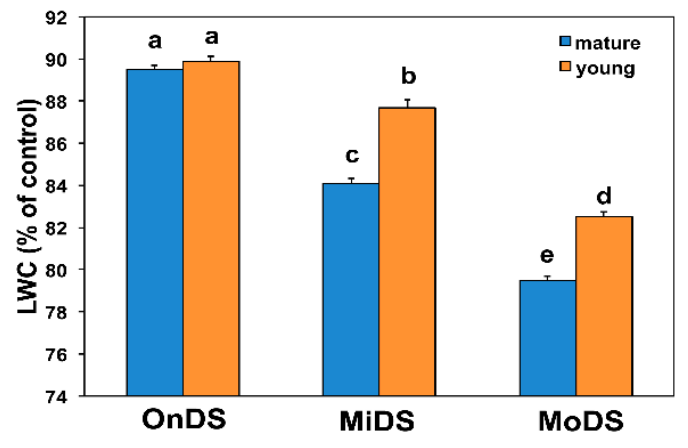

(a)

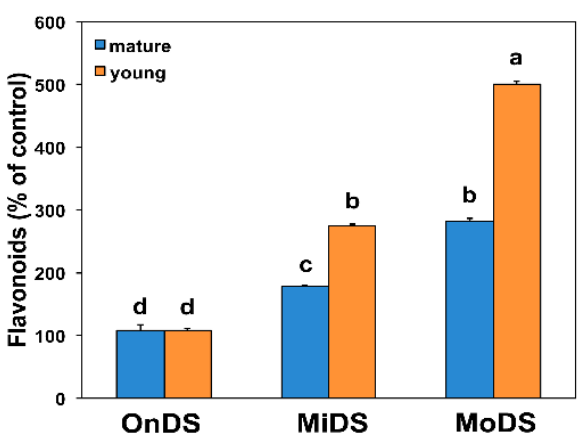

(b)

Figure 1. The relative leaf water content (a) and the flavonoid content (b) expressed as percentage of control (well-watered plants), in A. thaliana young and mature leaves at the onset of drought stress (OnDS), at mild drought stress (MiDS) and at moderate drought stress (MoDS). Error bars represent \pm standard error of the mean $(n=5-6)$. Bars with different lowercase letters are significantly different at $p<0.05$.

\subsection{Young Leaves Accumulated Greater Amounts of Flavonoids and Less MDA under Drought Stress}

At the OnDS, there was no difference between ML and YL in flavonoid content, but, at MiDS and MoDS, YL accumulated a significantly greater amount of flavonoids than ML (Figure 1b). Young leaves at MiDS accumulated the same amount of flavonoids as ML at MoDS (Figure 1b).

The level of lipid peroxidation in ML and YL during DS treatments was assessed by malondialdehyde (MDA) content that was determined by the reaction with 2-thiobarbituric acid (TBA). Even during OnDS, YL possessed lower level of oxidative stress compared to $\mathrm{ML}$, as evident by the lower level of lipid peroxidation (Figure 2a). In addition, during MiDS and MoDS the level of lipid peroxidation was lower in YL compared to ML (Figure 2a). 


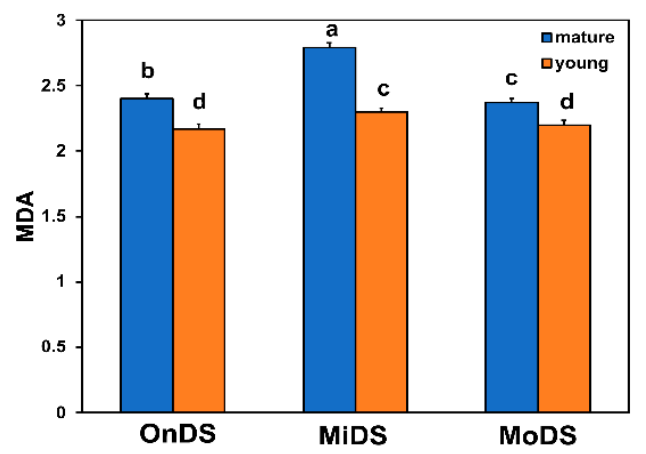

(a)

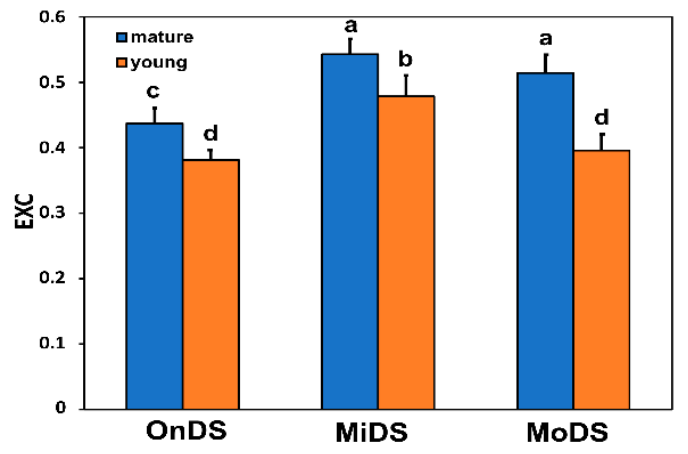

(b)

Figure 2. Changes in the level of lipid peroxidation, measured as nmol MDA $g^{-1}$ fresh weight (a) and in the excess excitation energy (EXC), estimated according to Demmig-Adams et al. [60] as: $F_{v}{ }^{\prime} / F_{m}{ }^{\prime} \times\left(1-\mathrm{q}_{p}\right)(\mathbf{b})$, in $A$. thaliana young and mature leaves at the onset of drought stress (OnDS), at mild drought stress (MiDS) and at moderate drought stress (MoDS). Error bars represent \pm standard error of the mean $(n=5-6)$. Bars with different lowercase letters are significantly different at $p<0.05$.

\subsection{Excess Excitation Energy in Young and Mature Leaves under Drought Stress}

The level of excess excitation energy (EXC), estimated as $F_{v}{ }^{\prime} / F_{m}{ }^{\prime} \times\left(1-\mathrm{q}_{p}\right)$ [60], was lower at the OnDS in YL, compared to ML, and remained lower in also YL, during MiDS and MoDS (Figure 2b). Young leaves at MoDS managed to possess an even lower level of EXC than YL at MiDS (Figure 2b). The low level of EXC of YL at MoDS was at the same level as the EXC of YL at the OnDS (Figure 2b).

\subsection{Light Energy Utilization in Photosystem II and Excess Excitation Pressure of Young and Mature Leaves}

The effective quantum yield of photochemistry ( $\left.\Phi_{P S I I}\right)$ in mature leaves (ML) decreased more at mild drought stress (MiDS) than at moderate drought stress (MoDS) (Figure 3a). These decreases were not compensated by the regulated energy dissipated in PSII $\left(\Phi_{N P Q}\right)$ (Figure $\left.3 b\right)$, thus MiDS-ed ML showed the highest values of non-regulated energy dissipated in PSII $\left(\Phi_{N O}\right)$, followed by MoDS-ed ML (Figure 4a). MoDS-ed YL showed higher $\Phi_{P S I I}$ values even from the onset of drought stress (OnDS) ML and from the MiDS-ed YL (Figure 3a). The highest $\Phi_{P S I I}$ values were recorded at all light intensities at the OnDS-ed YL (Figure 3a), accompanied by the highest $\Phi_{N P Q}$ values at all light intensities (Figure $3 b$ ), thus presenting the lowest level of non-regulated energy dissipated in PSII $\left(\Phi_{N O}\right)$ (Figure $\left.4 a\right) . \Phi_{N O}$ values of MoDS-ed YL were lower from those of MiDS-ed YL that have the same $\Phi_{N O}$ as the OnDS ML (Figure 4a). The highest excitation pressure (1- $\left.q_{p}\right)$ was recorded at MiDS-ed ML, followed by MoDS-ed ML and MiDS-ed YL (Figure 4b). The lowest $1-\mathrm{q}_{p}$ values were recorded at the OnDS-ed YL, followed by MoDS-ed YL (Figure $4 b$ ).

Mature leaves (ML) at the onset of DS and at MoDS, at light intensities up to $300 \mu \mathrm{mol}$ photons $\mathrm{m}^{-2} \mathrm{~s}^{-1}$, showed the same quantum yield of photochemistry ( $\Phi_{\text {PSII }}$ ) (Figure 3a), but those at the OnDS were more capable of dissipating the absorbed light energy that was not used for photochemistry as heat $\left(\Phi_{N P Q}\right)$, than that of MoDS ML (Figure $3 b$ ), resulting in lower $\Phi_{N O}$ values of the OnDS-ed ML (Figure 4a). Light intensities above $300 \mu \mathrm{mol}$ photons $\mathrm{m}^{-2} \mathrm{~s}^{-1}$, that acted synergistically with the increased severity of DS, decreased the fraction of light energy that was used for photochemistry of MoDS-ed ML, compared to the OnDS-ed ML (Figure 3a), but stimulated their capability to dissipate the excess light (Figure $2 b$ ) as heat $\left(\Phi_{N P Q}\right.$, Figure $\left.3 b\right)$. However, it seems that the increased $\Phi_{N P Q}$ was not sufficient to keep the fraction of non-regulated energy dissipated in PSII $\left(\Phi_{N O}\right)$ of MoDS-ed ML at a lower level than that of the OnDS-ed ML (Figure 4a), thus resulting in excess excitation pressure $\left(1-\mathrm{q}_{p}\right.$ ) of MoDS-ed ML (Figure $\left.4 \mathrm{~b}\right)$. 


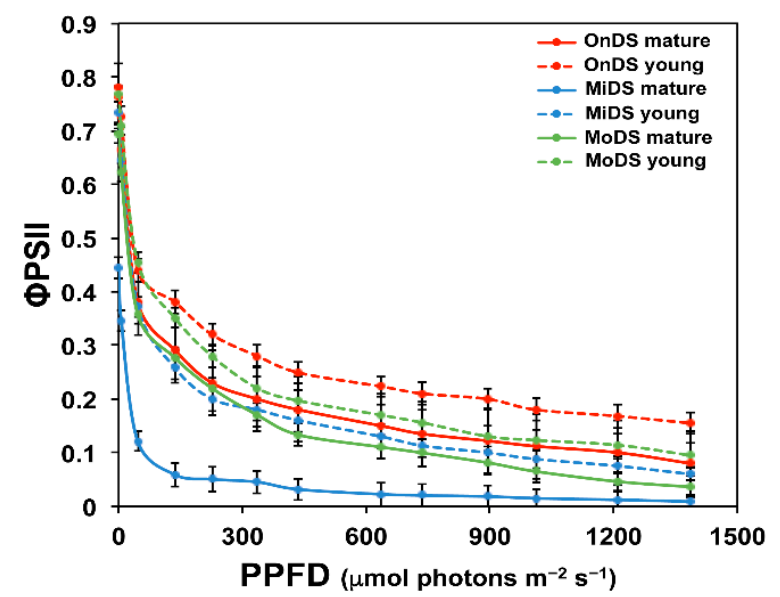

(a)

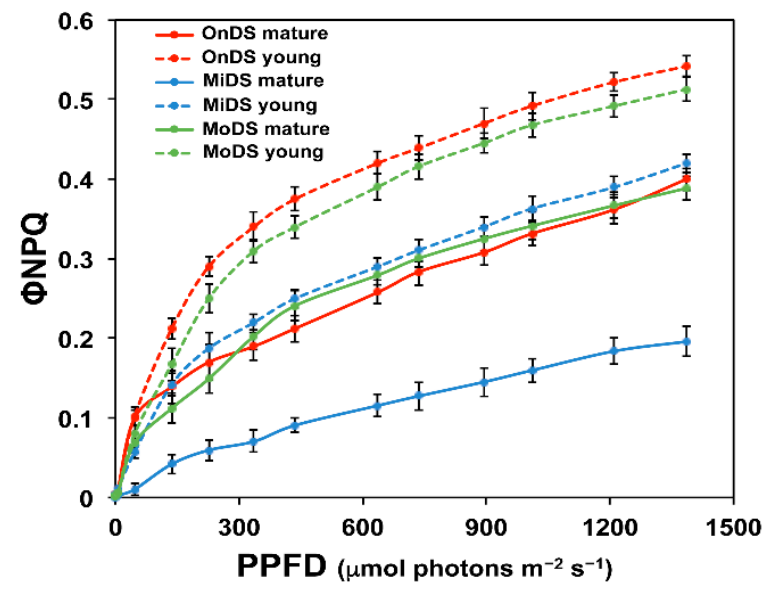

(b)

Figure 3. Light response curves of the effective quantum yield of photochemistry $\left(\Phi_{P S I I}\right)(\mathbf{a})$ and of the regulated energy dissipated in PSII $\left(\Phi_{N P Q}\right)(\mathbf{b})$, in A. thaliana young and mature leaves, at the onset of drought stress (OnDS), at mild drought stress (MiDS) and at moderate drought stress (MoDS). Error bars represent \pm standard error of the mean $(n=5-6)$.

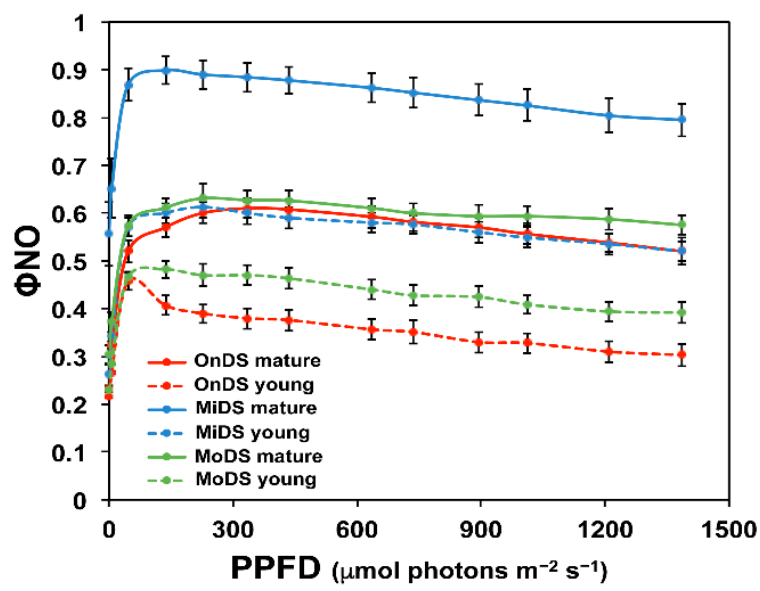

(a)

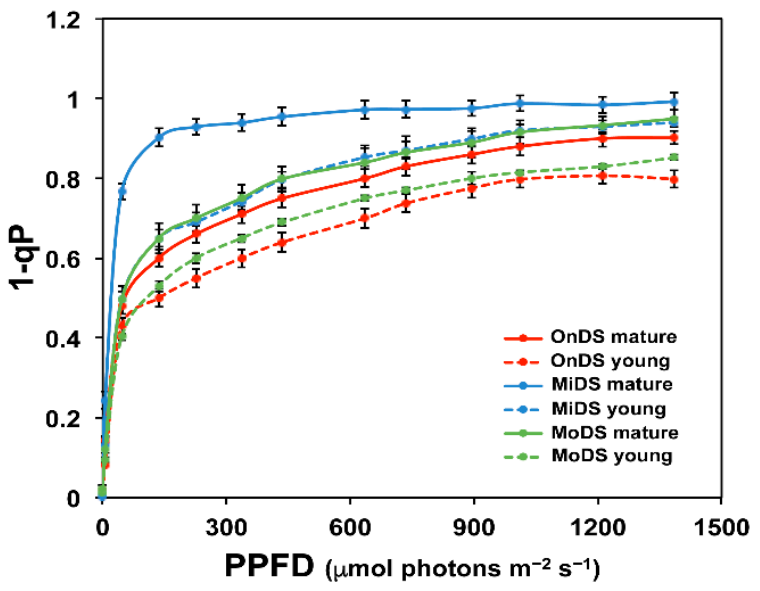

(b)

Figure 4. Light response curves of non-regulated energy dissipated in PSII $\left(\Phi_{N O}\right)(\mathbf{a})$ and of excitation pressure $\left(1-\mathrm{q}_{p}\right)(\mathbf{b})$, in $A$. thaliana young and mature leaves at the onset of drought stress (OnDS), at mild drought stress (MiDS) and at moderate drought stress (MoDS). Error bars represent \pm standard error of the mean $(n=5-6)$.

\subsection{Correlation Analysis in Light Energy Utilization in Photosystem II and Lipid Peroxidation of Young and Mature Leaves under Drought Stress}

The maximum efficiency of PSII photochemistry $\left(F_{v} / F_{m}\right)$, at the three DS treatments, in both YL and ML, was significantly negatively correlated to the level of lipid peroxidation, measured as malondialdehyde (MDA) (Figure 5a). The decline in $F_{v} / F_{m}$ is also showing the degree of PSII photoinhibition [43]. The level of excitation pressure $\left(1-\mathrm{q}_{p}\right)$, estimated at the growth light intensity of $136 \mu \mathrm{mol}$ photons $\mathrm{m}^{-2} \mathrm{~s}^{-1}$ was strongly correlated at the three DS treatments in both YL and ML, to the level of MDA (Figure 5b). In addition, the maximum efficiency of PSII photochemistry $\left(F_{v} / F_{m}\right)$ was significantly negatively correlated, at the three DS treatments in both YL and ML, to the level of excitation pressure $\left(1-q_{p}\right)$ at the growth light intensity of $136 \mu \mathrm{mol}$ photons $\mathrm{m}^{-2} \mathrm{~s}^{-1}$ (Figure $5 \mathrm{c}$ ). The effective quantum yield of PSII photochemistry $\left(\Phi_{P S I I}\right)$, at the growth light intensity of $136 \mu \mathrm{mol}$ photons $\mathrm{m}^{-2}$ $\mathrm{s}^{-1}$, was also significantly negatively correlated, at the three DS treatments in both YL and ML, to the level of $1-q_{p}$ (Figure $5 d$ ). 
(a)

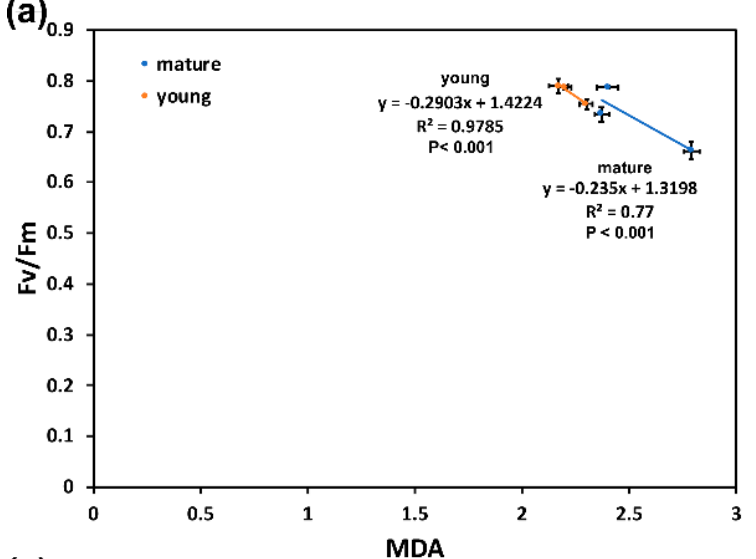

(c)

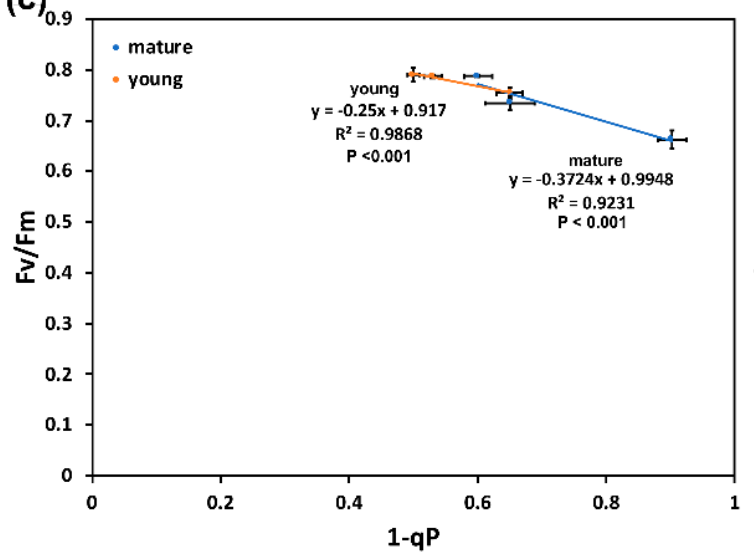

(b)

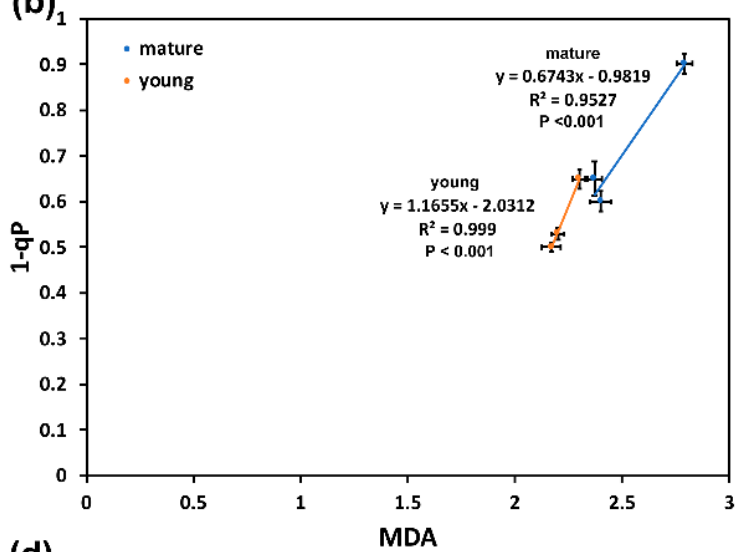

(d)

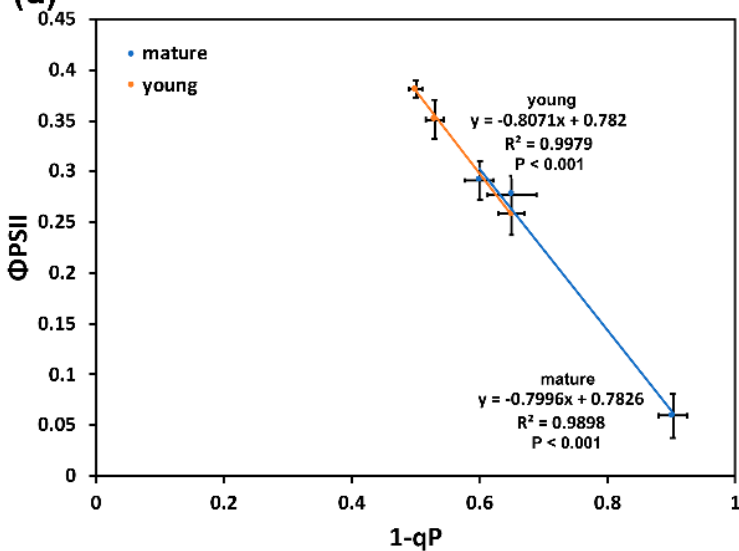

Figure 5. The relationship between the maximum efficiency of PSII photochemistry $\left(F_{v} / F_{m}\right)$ and the level of lipid peroxidation, measured as malondialdehyde (MDA) (a), the level of MDA with the level of excitation pressure $\left(1-q_{p}\right)(\mathbf{b})$, the level of excitation pressure $\left(1-\mathrm{q}_{p}\right)$ with $F_{v} / F_{m}(\mathrm{c})$ and the effective quantum yield of PSII photochemistry $\left(\Phi_{P S I I}\right)$ with $1-\mathrm{q}_{p}(\mathbf{d})$, in both $A$. thaliana young leaves (YL) and mature leaves (ML) at the three DS treatments. Error bars represent \pm standard error of the mean $(n=5-6)$.

The quantum yield of non-regulated energy dissipated in PSII $\left(\Phi_{N O}\right)$ was significantly positively correlated, at the three DS treatments, in both YL and ML, to both the level of MDA (Figure 6a) and the level of excitation pressure $\left(1-q_{p}\right)$ (Figure $6 b$ ).

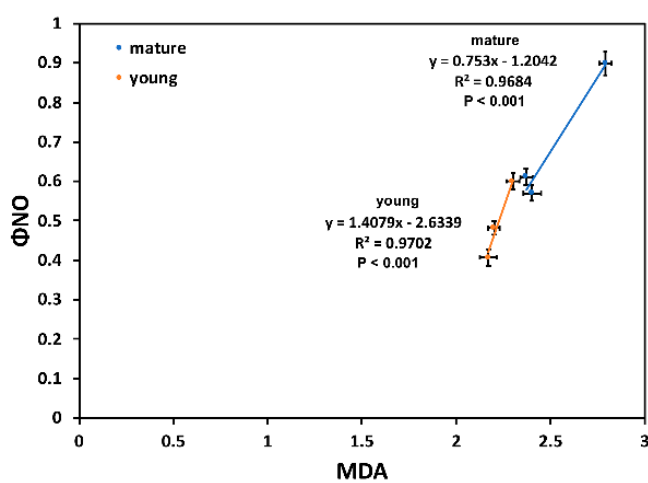

(a)

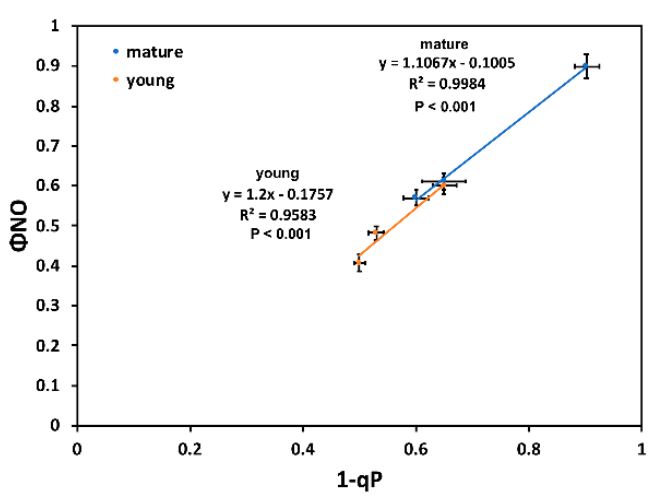

(b)

Figure 6. The relationship between the quantum yield of non-regulated energy dissipated in PSII ( $\left.\Phi_{N O}\right)$ and the level of MDA) (a) and the level of excitation pressure $\left(1-\mathrm{q}_{p}\right)$ with $\Phi_{N O}(\mathbf{b})$, in both YL and ML, at the three DS treatments. Error bars represent \pm standard error of the mean $(n=5-6)$. 
2.6. Correlation Analysis between Leaf Water Content and Flavonoid Accumulation of Young and Mature Leaves under Drought Stress

The leaf water content (LWC) expressed as percentage of control (well-watered plants), at the three DS treatments, in both YL and ML, was significantly negatively correlated to flavonoid accumulation, also expressed as percentage of control (Figure S1).

\section{Discussion}

Under most environmental stresses, the absorbed light energy exceeds what it can be used, resulting in ROS generation, such as superoxide anion radical $\left(\mathrm{O}_{2}{ }^{\bullet-}\right)$, hydrogen peroxide $\left(\mathrm{H}_{2} \mathrm{O}_{2}\right)$ and ${ }^{1} \mathrm{O}_{2}[38,41,61-66]$. When ROS production is not counterbalanced by the antioxidant defense network, photo-oxidative stress occurs [24,41,61,62]. ROS-antioxidant interaction provides important knowledge for the redox state that impacts gene expression associated with plant stress responses modulating the initiation of photosynthetic acclimation or cell death [66-70].

The higher flavonoid accumulation of YL at MiDS than ML at the OnDS (Figure 1b) resulted in their ability, at PAR higher than $300 \mu \mathrm{mol} \mathrm{m}{ }^{-2} \mathrm{~s}^{-1}$, to maintain lower ${ }^{1} \mathrm{O}_{2}$ generation, as observed by the lower $\Phi_{N O}$ values (Figure 4a). $\Phi_{N O}$ consists of chlorophyll fluorescence interior conversions and intersystem crossing, which leads to the generation of ${ }^{1} \mathrm{O}_{2}$ via the triplet state of chlorophyll $\left({ }^{3} \mathrm{chl}^{*}\right)$ that reacts with oxygen $\left(\mathrm{O}_{2}\right)$ [71-77]. Thus, the lower $\Phi_{N O}$ values suggest a lower level of ${ }^{1} \mathrm{O}_{2}$ formation in $\mathrm{YL}$, compared to ML. Singlet oxygen is a highly damaging ROS created in PSII [71,75-77] and high concentrations of ${ }^{1} \mathrm{O}_{2}$ activate programmed cell death $[69,70]$. Accumulation of excess excitation energy (EXC) may lead to the proportional increase in the production of ${ }^{1} \mathrm{O}_{2}$, that can cause specific damage [78]. In accordance to this, the light response curves of excitation pressure $\left(1-\mathrm{q}_{p}\right)$ and of the non-regulated energy dissipated in PSII $\left(\Phi_{N O}\right)$ show a similar trend (Figure 4), with a significant positive correlation to be observed (Figure 6b). Excitation pressure $\left(1-q_{p}\right)$ was also strongly correlated with the level of lipid peroxidation (Figure $5 b$ ), that was also strongly correlated with $\Phi_{N O}$ (Figure 6a).

While scavenging of $\mathrm{O}_{2} \bullet-$ is mainly achieved by the antioxidant enzyme, superoxide dismutase [41,79], ${ }^{1} \mathrm{O}_{2}$ can only be controlled by non-enzymatic antioxidants [51]. Singlet oxygen is quenched by the plant antioxidants $\beta$-carotene, $\alpha$-tocopherol, plastoquinones, zeaxanthin and flavonoids $[51,71,72,77]$. However, ROS produced in chloroplasts are not only creating oxidative stress but also confer significant biological functions, such as redox signaling in the regulation of leaf development and translating information from the environment $[69,70,74,80-82]$. NPQ has also been suggested to be involved in the mechanism of plant acclimation to biotic or abiotic stress and to be a major component of the systemic acquired resistance $[66,70,83-86]$.

Mature leaves maintained higher PSII photochemistry $\left(\Phi_{P S I I}\right)$ at MoDS than YL at MiDS at low PAR $\left(<300 \mu \mathrm{mol} \mathrm{m}^{-2} \mathrm{~s}^{-1}\right)$ (Figure 3a), but YL, by dissipating slightly more absorbed light energy as heat $\left(\Phi_{N P Q}\right)$ (Figure $\left.3 b\right)$, retained lower singlet oxygen $\left({ }^{1} \mathrm{O}_{2}\right)$ generation, as observed by lower $\Phi_{N O}$ (Figure 4a). An increase in the values of $\Phi_{P S I I}$ and a decrease in the values of $\Phi_{N P Q}$ is observed when the leaf gets older [87]. In young leaves, only a fraction of absorbed light energy is utilized in photochemistry via $\mathrm{CO}_{2}$ assimilation, because carbon assimilation capacity is developed later than light capture ability [88-91], thus they have to activate NPQ to dissipate excessive excited energy as heat and regulate photosynthetic electron flow during photosynthetic induction $[92,93]$ in order to avoid the harmful generation of ${ }^{1} \mathrm{O}_{2}$ that can damage the photosynthetic apparatus $[37,91,94]$. Thus, YL, by regulating NPQ, can maintain a balanced ROS level that allows growth $[69,70,85,86,95]$ and prevents their oxidative damage [22]. Dissipation of excess excitation energy in YL plays an important role in order to avoid possible photodamage to PSII under DS conditions [91]. PSII photodamage is caused by ROS produced by excess excitation or/and by other photosensitizers, primarily the Mn cluster [31]. 
Drought stress leads to decreases in the fraction of open reaction centers of PSII $\left(q_{p}\right)$, reductions in the effective quantum yield of photochemistry $\left(\Phi_{P S I I}\right)$ and increases in the regulated energy dissipated in PSII $\left(\Phi_{N P Q}\right)$ and these changes become bigger with stress duration $[15,21,22,96,97]$. Photochemical quenching of chlorophyll $a$ fluorescence $\left(\mathrm{q}_{p}\right)$ estimates changes in the redox state of $\mathrm{Q}_{\mathrm{A}}$ and, thus, the reduction level of PSII reaction centers, while $1-q_{p}$, the fraction of reduced quinone $Q_{A}$, illustrates the degree of excitation pressure on PSII [34,98]. The higher $1-\mathrm{q}_{p}$, the higher the excitation pressure $[44,99,100]$. Mature leaves at MoDS and YL at MiDS accumulated the same level of flavonoids (Figure 1b) and experienced the same level of lipid peroxidation (Figure 2a), exhibiting the same level of excitation pressure $\left(1-\mathrm{q}_{p}\right)$ (Figure $4 \mathrm{~b}$ ).

MoDS A. thaliana leaves had a significantly higher flavonoid accumulation that serves as a sufficient antioxidant mechanism destroying ROS [51,58]. As LWC decreased, flavonoid accumulation increased and a negative significant correlation between LWC and flavonoids was observed (Figure S1). Thus, flavonoid accumulation may have an important role in the acclimation process to DS. Flavonoid accumulation, in YL under MiDS and in ML under MoDS (Figure 1b), was not enough to prevent ${ }^{1} \mathrm{O}_{2}$ generation, as observed by $\Phi_{N O}$ values, but it appears that it was sufficient in YL under MoDS (Figure 1b), that resulted in reduced excess light availability, similar to the level of the OnDS-ed YL (Figure $2 b$ ), with only slightly higher excitation pressure from them (Figure $4 b$ ).

Chlorophyll fluorescence analysis has been widely used to acquire knowledge about the function of the photosynthetic machinery and for the assessment of photosynthetic tolerance mechanisms to biotic [66,86,101,102] and abiotic stresses [103-108], including drought stress [21,22,96,108-110]. However, DS may not affect a plant leaf uniformly [97], thus photosynthetic performance may be extremely heterogeneous at the leaf surface, denoting conventional chlorophyll fluorescence measurements non-characteristic of the physiological status of the entire leaf [111-113]. This disadvantage overcomes chlorophyll fluorescence imaging analysis, which permits the detection of spatiotemporal heterogeneity at the total leaf surface [114].

Among the chlorophyll fluorescence parameters used for DS monitoring, evaluation and selection of drought-tolerant species, decreases in the maximum efficiency of PSII photochemistry $\left(F_{v} / F_{m}\right)$ were mostly used [109]. However, there are research results that question the efficacy of $F_{v} / F_{m}$ as a good indicator of DS $[109,115,116]$. Recently, the reduction status of the plastoquinone pool, or, in other words, PSII excitation pressure, was found to be the most sensitive and appropriate indicator to probe photosynthetic function and determine the impact of biotic and abiotic stresses on leaf photosynthesis $[66,117]$. Our results collaborate this opinion, suggesting the use of PSII excitation pressure $\left(1-\mathrm{q}_{p}\right)$ as a good indicator to reveal short- or long-term stress impact on the mechanisms of PSII functionality.

Drought stress enhances flavonoid accumulation [55,56], which, in turn, can reduce ROS accumulation, improving the antioxidant capacity and, consequently, resulting in drought acclimation [57-59]. Flavonoid production is one of the strategies used by native species living in extreme environments to avoid the oxidative damage caused by drought $[118,119]$. Our study indicates that higher concentrations of flavonoids in YL, compared to ML (Figure 1b), promote acclimation to MoDS of YL by helping to prevent ${ }^{1} \mathrm{O}_{2}$ generation, as observed by the lower $\Phi_{N O}$ values in $\mathrm{YL}$, compared to ML (Figure 4a). Differences in drought tolerance between YL and ML of Arabidopsis thaliana reflect their ability to respond to oxidative stress by increasing flavonoid accumulation.

Overall, acclimation of YL to MoDS (and not to MiDS) was correlated with higher flavonoid accumulation, decreased lipid peroxidation, higher PSII photochemistry ( $\left.\Phi_{\text {PSII }}\right)$ than ML leaves, lower excitation pressure $\left(1-q_{p}\right)$, lower excess excitation energy (EXC) and also a higher capacity to maintain low $\Phi_{N O}$, which can be effectively used for selecting drought tolerant plants. Breeding of plants with high flavonoid content that confers drought resistance and resilience could help crop production under future climate change [78]. 


\section{Materials and Methods}

\subsection{Plant Material, Growth Conditions and Drought Stress Treatment}

Arabidopsis thaliana ecotype Columbia (Col-0) seedlings were grown in a growth chamber with controlled environmental conditions, under a long day photoperiod of $14 \mathrm{~h} / 10 \mathrm{~h}$, with $40 \pm 5 / 55 \pm 5 \%$ day/night humidity, temperature of $22 \pm 1 / 19 \pm 1{ }^{\circ} \mathrm{C}$ day/night and light intensity of $130 \pm 10 \mu \mathrm{mol}$ photons $\mathrm{m}^{-2} \mathrm{~s}^{-1}$. Drought stress was imposed by withholding water for a period up to 10 days on 4-week-old Arabidopsis plants [14]. The two developmental leaf stages that were studied were fully developed mature leaves (ML) and developing young leaves $(\mathrm{YL})$ from plants whose watering stopped twenty-four hours before sampling and characterized as onset of drought stress (OnDS), six days before sampling, characterized as mild drought stress (MiDS), and ten days before sampling, characterized as moderate drought stress (MoDS), representing three categories of drought stressed (DS) plants. As young leaves were considered those in the middle of the leaf rosette with 1.5-2 cm length, while the typical length of mature leaves in the rosette was $4.1 \pm 0.5 \mathrm{~cm}[21,22]$.

\subsection{Soil and Leaf Water Status}

Soil volumetric water content (SWC) in $\mathrm{m}^{3} \mathrm{~m}^{-3}$ was measured as described previously [91] with a 5TE (Decagon Devices, Pullman, WA, USA) soil moisture sensor that uses a two-sensor array to measure electrical conductivity, coupled to the read-out device ProCheck (Decagon Devices, Pullman, WA, USA).

Plant leaf water status was determined by measuring the leaf water content (LWC) by the electronic moisture balance (MOC- 120H, Shimadzu, Tokyo, Japan) using the formula: $(\mathrm{FW}-\mathrm{DW}) / \mathrm{DW} \times 100 \%$, where $\mathrm{FW}$ is the fresh weight and DW refers to dry weight [21].

\subsection{Lipid Peroxidation Measurements}

Lipid peroxidation was measured as malondialdehyde (MDA) content determined by reaction with 2-thiobarbituric acid (TBA) [120]. The concentration of MDA was calculated from absorbance read at $440 \mathrm{~nm}, 532 \mathrm{~nm}$ and $600 \mathrm{~nm}$ spectrophotometrically (PharmaSpec UV-1700; Shimadzu, Tokyo, Japan) as follows:

$$
\begin{gathered}
{\left[(\text { Abs 532 }+ \text { TBA })-\left(\text { Abs } 600_{+\mathrm{TBA}}\right)-\left(\text { Abs } 532_{-\mathrm{TBA}}-\text { Abs } 600_{-\mathrm{TBA}}\right)\right]=\mathrm{A}} \\
{\left[\left(\text { Abs } 440_{+\mathrm{TBA}}-\text { Abs } 600_{+} \text {TBA }\right) 0.0571\right]=\mathrm{B}}
\end{gathered}
$$

where $532 \mathrm{~nm}$ is the maximum absorbance of the TBA-MDA complexes, $600 \mathrm{~nm}$ is the correction factor for nonspecific turbidity and $440 \mathrm{~nm}$ is the correction factor for sucrose interference.

Finally, MDA equivalents were calculated as:

$$
\text { MDA equivalents }\left(\mathrm{nmol} \mathrm{mL} \mathrm{m}^{-1}\right)=(\mathrm{A}-\mathrm{B}) / 157,000 \times 10^{6}
$$

where 157,000 is the molar extinction coefficient for MDA.

\subsection{Determination of Flavonoids}

Leaf discs ( $1 \mathrm{~cm}$ in diameter), from each treatment of $A$. thaliana mature leaves (ML) and young leaves $(\mathrm{YL})$, from control plants and DS plants, were ground into fine powder in liquid nitrogen. For flavonoid determination, the frozen powder was extracted in $10 \mathrm{~cm}^{3}$ of acidified methanol ( $\mathrm{HCl}$ :methanol, 1:99, v/v), as described by Havaux and Kloppstech [121]. Absorption spectra of the extracts were determined after centrifugation at $5000 \times g$ for $10 \mathrm{~min}$, using a PharmaSpec UV-1700 spectrophotometer (Shimadzu, Tokyo, Japan). Absorbance was read at $350 \mathrm{~nm}$ and flavonoid content was expressed as absorbance $\mathrm{cm}^{-2}$ [121]. 


\subsection{Chlorophyll Fluorescence Analysis}

Chlorophyll fluorescence was measured in dark-adapted $A$. thaliana young and mature leaves using an imaging-PAM fluorometer (Walz, Effeltrich, Germany), as described previously [91]. Light curves were used for the calculation of various fluorescence parameters at photosynthetic photon flux density (PPFD) of 0, 6, 46, 136, 226, 336, 436, 636, 736, 894, 1011, 1211 and $1386 \mu \mathrm{mol}$ photons $\mathrm{m}^{-2} \mathrm{~s}^{-1}$. The chlorophyll fluorescence parameters measured were the minimum chlorophyll $a$ fluorescence in the dark ( $F o)$, the maximum chlorophyll $a$ fluorescence in the dark $\left(F_{m}\right)$, the maximum chlorophyll $a$ fluorescence in the light $\left(F_{m}{ }^{\prime}\right)$ and the steady-state photosynthesis in the light $\left(F_{S}\right)$. The minimum chlorophyll $a$ fluorescence in the light was calculated by the Imaging Win V2.41a software (Heinz Walz GmbH, Effeltrich, Germany) as $F^{\prime}=F_{o} /\left(F_{v} / F_{m}+F o / F_{m}{ }^{\prime}\right)$ [122]. The maximum efficiency of PSII photochemistry $\left(F_{v} / F_{m}\right.$, where $\left.F_{v}=F_{m}-F o\right)$ [123], the effective quantum yield of PSII photochemistry $\left(\Phi_{P S I I}=\left[F_{m}{ }^{\prime}-F_{s}\right] / F_{m}{ }^{\prime}\right)[124,125]$, the quantum yield of regulated non-photochemical energy loss in PSII $\left(\Phi_{N P Q}=F_{s} / F_{m}{ }^{\prime}-F_{s} / F_{m}\right)$ [126] and the quantum yield of non-regulated energy dissipated in PSII $\left(\Phi_{N O}=F_{s} / F_{m}\right)$ [126] were calculated. We also measured the relative PSII electron transport rate $\left(E T R=\Phi_{\text {PSII }} \times\right.$ PAR $\times \mathrm{c} \times$ abs, where PAR is the photosynthetically active radiation, $\mathrm{c}$ is 0.5 and abs is the total light absorption of the leaf taken as 0.84), the proportion of closed PSII reaction centers, referred to as excitation pressure and calculated as $1-\mathrm{q}_{p}[98]$, where $\mathrm{q}_{p}=\left[F_{m}{ }^{\prime}-F_{s}\right] /\left[F_{m}{ }^{\prime}-F o^{\prime}\right]$, the non-photochemical quenching, that reflects heat dissipation of excitation energy $\left(\mathrm{NPQ}=\left[F_{m}-F_{m}{ }^{\prime}\right] / F_{m}{ }^{\prime}[127]\right.$, and the excess excitation energy $\left(\mathrm{EXC}=F_{v}{ }^{\prime} / F_{m}{ }^{\prime} \times\left(1-\mathrm{q}_{p}\right)\right.$ [60].

A linear regression analysis was also performed [14].

\subsection{Statistical Analysis}

Each treatment was analyzed with five-six replicates from five-six different leaves from different plants. A standard error (SE) was calculated and data were expressed as mean \pm SE $(n=5-6)$. Statistically significant differences between the treatments were analyzed by analysis of variance (ANOVA) using the software StatView (SAS Institute, Cary, NC, USA) [22].

Supplementary Materials: Figure S1: The relationship between leaf water content and flavonoid accumulation.

Author Contributions: Conceptualization, I.S. and M.M.; methodology, I.S., J.M., G.O. and M.M.; validation, I.S., J.M. and M.M.; formal analysis, I.S. and M.M.; investigation, I.S., J.M., G.O. and M.M.; resources, M.M.; data curation, I.S., J.M., G.O. and M.M.; writing-original draft preparation, I.S. and M.M.; writing—review and editing, I.S., J.M., G.O. and M.M.; visualization, I.S., J.M. and M.M.; supervision, M.M.; project administration, M.M.; funding acquisition, M.M. All authors have read and agreed to the published version of the manuscript.

Funding: This research received no external funding.

Institutional Review Board Statement: Not applicable.

Informed Consent Statement: Not applicable.

Data Availability Statement: The data presented in this study are available in this article and in Supplementary Materials.

Conflicts of Interest: The authors declare no conflict of interest.

Sample Availability: Seeds of the plant material used in this study are available from the authors.

\section{References}

1. Bray, E.A. Plant responses to water deficit. Trends Plant Sci. 1997, 2, 48-54. [CrossRef]

2. Ma, Y.; Cao, J.; Chen, Q.; He, J.; Liu, Z.; Wang, J.; Li, X.; Yang, Y. The Kinase CIPK11 Functions as a Negative Regulator in Drought Stress Response in Arabidopsis. Int. J. Mol. Sci. 2019, 20, 2422. [CrossRef]

3. Dai, A. Increasing drought under global warming in observations and models. Nat. Clim. Chang. 2012, 3, 52-58. [CrossRef] 
4. Urban, L.; Aarrouf, J.; Bidel, L.P.R. Assessing the Effects of Water Deficit on Photosynthesis Using Parameters Derived from Measurements of Leaf Gas Exchange and of Chlorophyll a Fluorescence. Front. Plant Sci. 2017, 8, 2068. [CrossRef] [PubMed]

5. Osmolovskaya, N.; Shumilina, J.; Kim, A.; DiDio, A.; Grishina, T.; Bilova, T.; Keltsieva, O.A.; Zhukov, V.; Tikhonovich, I.; Tarakhovskaya, E.; et al. Methodology of Drought Stress Research: Experimental Setup and Physiological Characterization. Int. J. Mol. Sci. 2018, 19, 4089. [CrossRef]

6. Zhu, J.K. Abiotic stress signaling and responses in plants. Cell 2016, 167, 313-324. [CrossRef] [PubMed]

7. Feng, Y.; Wang, Y.; Zhang, G.; Gan, Z.; Gao, M.; Lv, J.; Wu, T.; Zhang, X.; Xu, X.; Yang, S.; et al. Group-C/S1 bZIP heterodimers regulate MdIPT5b to negatively modulate drought tolerance in apple species. Plant J. 2021. [CrossRef]

8. Blum, A. Osmotic adjustment is a prime drought stress adaptive engine in support of plant production. Plant Cell Environ. 2017, 40, 4-10. [CrossRef]

9. Hanjra, M.A.; Qureshi, M.E. Global water crisis and future food security in an era of climate change. Food Policy 2010, 35, 365-377. [CrossRef]

10. Harb, A.; Krishnan, A.; Ambavaram, M.M.R.; Pereira, A. Molecular and physiological analysis of drought stress in Arabidopsis reveals early responses leading to acclimation in plant growth. Plant Physiol. 2010, 154, 1254-1271. [CrossRef]

11. Verbruggen, N.; Hermans, C. Proline accumulation in plants: A review. Amino Acids 2008, 35, 753-759. [CrossRef]

12. Szabados, L.; Savoure, A. Proline: A multifunctional amino acid. Trends Plant Sci. 2010, 15, 89-97. [CrossRef]

13. Moustakas, M.; Sperdouli, I.; Kouna, T.; Antonopoulou, C.I.; Therios, I. Exogenous proline induces soluble sugar accumulation and alleviates drought stress effects on photosystem II functioning of Arabidopsis thaliana leaves. Plant Growth Regul. 2011, 65, 315-325. [CrossRef]

14. Sperdouli, I.; Moustakas, M. Interaction of proline, sugars, and anthocyanins during photosynthetic acclimation of Arabidopsis thaliana to drought stress. J. Plant Physiol. 2012, 169, 577-585. [CrossRef] [PubMed]

15. Bano, H.; Athar, H.R.; Zafar, Z.U.; Ogbaga, C.C.; Ashraf, M. Peroxidase activity and operation of photo-protective component of NPQ play key roles in drought tolerance of mung bean [Vigna radiata (L.) Wilcziek]. Physiol. Plant. 2021, 172, 603-614. [CrossRef] [PubMed]

16. Xu, Q.; Liesche, J. Sugar export from Arabidopsis leaves: Actors and regulatory strategies. J. Exp. Bot. 2021. [CrossRef]

17. Chen, Y.; Dubois, M.; Vermeersch, M.; Inzé, D.; Vanhaeren, H. Distinct cellular strategies determine sensitivity to mild drought of Arabidopsis natural accessions. Plant Physiol. 2021, 186, 1171-1185. [CrossRef] [PubMed]

18. Skirycz, A.; Vandenbroucke, K.; Clauw, P.; Maleux, K.; De Meyer, B.; Dhondt, S.; Pucci, A.; Gonzalez, N.; Hoeberichts, F.; Tognetti, V.B.; et al. Survival and growth of Arabidopsis plants given limited water are not equal. Nat. Biotechnol. 2011, 29, 212-214. [CrossRef]

19. Ma, X.; Sukiran, N.L.; Ma, H.; Su, Z. Moderate drought causes dramatic floral transcriptomic reprogramming to ensure successful reproductive development in Arabidopsis. BMC Plant Biol. 2014, 14, 164. [CrossRef]

20. Clauw, P.; Coppens, F.; De Beuf, K.; Dhondt, S.; Van Daele, T.; Maleux, K.; Storme, V.; Clement, L.; Gonzalez, N.; Inzé, D. Leaf responses to mild drought stress in natural variants of Arabidopsis. Plant Physiol. 2015, 167, 800-816. [CrossRef] [PubMed]

21. Sperdouli, I.; Moustakas, M. A better energy allocation of absorbed light in photosystem II and less photooxidative damage contribute to acclimation of Arabidopsis thaliana young leaves to water deficit. J. Plant Physiol. 2014, 171, 587-593. [CrossRef] [PubMed]

22. Sperdouli, I.; Moustakas, M. Leaf developmental stage modulates metabolite accumulation and photosynthesis contributing to acclimation of Arabidopsis thaliana to water deficit. J. Plant Res. 2014, 127, 481-489. [CrossRef] [PubMed]

23. Lawlor, D.W. Limitation to photosynthesis in water-stressed leaves: Stomata vs. metabolism and the role of ATP. Ann. Bot. 2002, 89, 871-885. [CrossRef] [PubMed]

24. Mittler, R. Abiotic stress, the field environment and stress combination. Trends Plant Sci. 2006, 11, 15-19. [CrossRef] [PubMed]

25. McKew, B.A.; Davey, P.; Finch, S.J.; Hopkins, J.; Lefebvre, S.C.; Metodiev, M.V.; Oxborough, K.; Raines, C.A.; Lawson, T.; Geider, R.J. The trade-off between the light-harvesting and photoprotective functions of fucoxanthin-chlorophyll proteins dominates light acclimation in Emiliania huxleyi (clone CCMP 1516). New Phytol. 2013, 200, 74-85. [CrossRef]

26. Nelson, N.; Junge, W. Structure and energy transfer in photosystems of oxygenic photosynthesis. Annu. Rev. Biochem. 2015, 84, 659-683. [CrossRef] [PubMed]

27. Sperdouli, I.; Moustakas, M. Differential blockage of photosynthetic electron flow in young and mature leaves of Arabidopsis thaliana by exogenous proline. Photosynthetica 2015, 53, 471-477. [CrossRef]

28. Flexas, J.; Bota, J.; Loreto, F.; Cornic, G.; Sharkey, T.D. Diffusive and metabolic limitations to photosynthesis under drought and salinity in C3 plants. Plant Biol. 2004, 6, 1-11. [CrossRef]

29. Lawlor, D.W.; Tezara, W. Causes of decreased photosynthetic rate and metabolic capacity in water-deficient leaf cells: A critical evaluation of mechanisms and integration of processes. Ann. Bot. 2009, 103, 561-579. [CrossRef]

30. Kanazawa, A.; Kramer, D.M. In vivo modulation of nonphotochemical exciton quenching (NPQ) by regulation of the chloroplast ATP synthase. Proc. Natl. Acad. Sci. USA 2002, 99, 12789-12794. [CrossRef]

31. Moustakas, M.; Bayçu, G.; Sperdouli, I.; Eroğlu, H.; Eleftheriou, E.P. Arbuscular mycorrhizal symbiosis enhances photosynthesis in the medicinal herb Salvia fruticosa by improving photosystem II photochemistry. Plants 2020, 9, 962. [CrossRef]

32. Lu, C.; Zhang, J. Effects of water stress on photosystem II photochemistry and its thermostability in wheat plants. J. Exp. Bot. 1999, 50, 1199-1206. [CrossRef] 
33. Murata, N.; Takahashi, S.; Nishiyama, Y.; Allakhverdiev, S.I. Photoinhibition of photosystem II under environmental stress. Biochim. Biophys. Acta 2007, 1767, 414-421. [CrossRef] [PubMed]

34. Moustaka, J.; Ouzounidou, G.; Sperdouli, I.; Moustakas, M. Photosystem II is more sensitive than photosystem I to $\mathrm{Al}^{3+}$ induced phytotoxicity. Materials 2018, 11, 1772. [CrossRef]

35. Zavafer, A.; Mancilla, C. Concepts of photochemical damage of Photosystem II and the role of excessive excitation. J. Photochem. Photobiol. C 2021, 47, 100421. [CrossRef]

36. Sheng, X.; Liu, Z.; Kim, E.; Minagawa, J. Plant and algal PSII-LHCII supercomplexes: Structure, evolution and energy transfer. Plant Cell Physiol. 2021. [CrossRef]

37. Müller, P.; Li, X.P.; Niyogi, K.K. Non-photochemical quenching. A response to excess light energy. Plant Physiol. 2001, 125, 1558-1566. [CrossRef]

38. Moustaka, J.; Moustakas, M. Photoprotective mechanism of the non-target organism Arabidopsis thaliana to paraquat exposure. Pest. Biochem. Physiol. 2014, 111, 1-6. [CrossRef] [PubMed]

39. Ruban, A.V. Nonphotochemical chlorophyll fluorescence quenching: Mechanism and effectiveness in protecting plants from photodamage. Plant Physiol. 2016, 170, 1903-1916. [CrossRef]

40. Takahashi, S.; Badger, M.R. Photoprotection in plants: A new light on photosystem II damage. Trends Plant Sci. 2011, 16, 53-60. [CrossRef]

41. Moustaka, J.; Tanou, G.; Adamakis, I.D.; Eleftheriou, E.P.; Moustakas, M. Leaf age dependent photoprotective and antioxidative mechanisms to paraquat-induced oxidative stress in Arabidopsis thaliana. Int. J. Mol. Sci. 2015, 16, 13989-14006. [CrossRef] [PubMed]

42. Havaux, M.; Eymery, F.; Porfirova, S.; Rey, P.; Dormann, P. Vitamin E protects against photoinhibition and photooxidative stress in Arabidopsis thaliana. Plant Cell 2005, 17, 3451-3469. [CrossRef] [PubMed]

43. Cazzaniga, S.; Dall' Osto, L.; Kong, S.-G.; Wada, M.; Bassi, R. Interaction between avoidance of photon absorption, excess energy dissipation and zeaxanthin synthesis against photooxidative stress in Arabidopsis. Plant J. 2013, 76, 568-579. [CrossRef] [PubMed]

44. Moustaka, J.; Ouzounidou, G.; Bayçu, G.; Moustakas, M. Aluminum resistance in wheat involves maintenance of leaf Ca ${ }^{2+}$ and $\mathrm{Mg}^{2+}$ content, decreased lipid peroxidation and $\mathrm{Al}$ accumulation, and low photosystem II excitation pressure. BioMetals 2016, 29, 611-623. [CrossRef] [PubMed]

45. Saito, K.; Yonekura-Sakakibara, K.; Nakabayashi, R.; Higashi, Y.; Yamazaki, M.; Tohge, T.; Fernie, A.R. The flavonoid biosynthetic pathway in Arabidopsis: Structural and genetic diversity. Plant Physiol. Biochem. 2013, 72, 21-34. [CrossRef]

46. Rice-Evans, C.; Miller, N.J.; Paganga, G. Structure antioxidant activity relationships of flavonoids and phenolic acids. Free Radic. Biol. Med. 1996, 20, 933-956. [CrossRef]

47. Robak, J.; Gryglewski, R.J. Flavonoids are scavengers of superoxide anions. Biochem. Pharmacol. 1988, 37, 837-841. [CrossRef]

48. Bergman, M.; Perelman, A.; Dubinsky, Z.; Grossman, S. Scavenging of reactive oxygen species by a novel glucurinated flavonoid antioxidant isolated and purified from spinach. Phytochemistry 2003, 62, 753-762. [CrossRef]

49. Galleano, M.; Verstraeten, S.V.; Oteiza, P.I.; Fraga, C.G. Antioxidant actions of flavonoids: Thermodynamic and kinetic analysis. Arch. Biochem. Biophys. 2010, 501, 23-30. [CrossRef]

50. Agati, G.; Brunetti, C.; Di Ferdinando, M.; Ferrini, F.; Pollastri, S.; Tattini, M. Functional roles of flavonoids in photoprotection: New evidence, lessons from the past. Plant Physiol. Biochem. 2013, 72, 35-45. [CrossRef]

51. Majer, P.; Neugart, S.; Krumbein, A.; Schreiner, M.; Hideg, É. Singlet oxygen scavenging by leaf flavonoids contributes to sunlight acclimation in Tilia platyphyllos. Environ. Exp. Bot. 2014, 100, 1-9. [CrossRef]

52. Csepregi, K.; Neugart, S.; Schreiner, M.; Hideg, É. Comparative evaluation of total antioxidant capacities of plant polyphenols. Molecules 2016, 21, 208. [CrossRef]

53. Brown, J.E.; Khodr, H.; Hider, R.C.; Rice-Evans, C.A. Structural dependence of flavonoid interactions with $\mathrm{Cu}^{2+}$ ions: Implications for their antioxidant properties. Biochem. J. 1998, 330, 1173-1178. [CrossRef] [PubMed]

54. Rice-Evans, C.; Miller, N.; Paganga, G. Antioxidant properties of phenolic compounds. Trends Plant Sci. 1997, 2, 152-159. [CrossRef]

55. Gao, S.S.; Wang, Y.L.; Yua, S.; Huang, Y.Q.; Liu, H.; Chen, W.; He, X.Y. Effects of drought stress on growth, physiology and secondary metabolites of two Adonis species in Northeast China. Sci. Hortic. 2020, 259, 108795. [CrossRef]

56. Talbi, S.; Rojas, J.; Sahrawy, M.; Rodríguez-Serrano, M.; Cárdenas, K.; Debouba, M.; Sandalio, L. Effect of drought on growth, photosynthesis and total antioxidant capacity of the Saharan plant Oudeneya africana. Environ. Exp. Bot. 2020, 176, 104099. [CrossRef]

57. Rao, M.J.; Xu, Y.; Tang, X.; Huang, Y.; Liu, J.; Deng, X.; Xu, Q. CsCYT75B1, a Citrus CYTOCHROME P450 gene, is involved in accumulation of antioxidant flavonoids and induces drought tolerance in transgenic Arabidopsis. Antioxidants 2020, 9, 161. [CrossRef]

58. Li, B.Z.; Fan, R.N.; Sun, G.L.; Sun, T.; Fan, Y.T.; Bai, S.L.; Guo, S.Y.; Huang, S.Q.; Liu, J.; Zhang, H.; et al. Flavonoids improve drought tolerance of maize seedlings by regulating the homeostasis of reactive oxygen species. Plant Soil 2021, 461, 389-405. [CrossRef]

59. Hasanuzzaman, M.; Bhuyan, M.H.M.B.; Zulfiqar, F.; Raza, A.; Mohsin, S.M.; Mahmud, J.A.; Fujita, M.; Fotopoulos, V. Reactive oxygen species and antioxidant defense in plants under abiotic stress: Revisiting the crucial role of a universal defense regulator. Antioxidants 2020, 9, 681. [CrossRef] 
60. Demmig-Adams, B.; Adams, W.W., III; Baker, D.H.; Logan, B.A.; Bowling, D.R.; Verhoeven, A.S. Using chlorophyll fluorescence to assess the fraction of absorbed light allocated to thermal dissipation of excess excitation. Physiol. Plant. 1996, 98, 253-264. [CrossRef]

61. Apel, K.; Hirt, H. Reactive oxygen species: Metabolism, oxidative stress, and signal transduction. Annu. Rev. Plant Biol. 2004, 55, 373-399. [CrossRef]

62. Gill, S.S.; Tuteja, N. Reactive oxygen species and antioxidant machinery in abiotic stress tolerance in crop plants. Plant Physiol. Biochem. 2010, 48, 909-930. [CrossRef]

63. Takagi, D.; Takumi, S.; Hashiguchi, M.; Sejima, T.; Miyake, C. Superoxide and singlet oxygen produced within the thylakoid membranes both cause photosystem I photoinhibition. Plant Physiol. 2016, 171, 1626-1634. [CrossRef]

64. Moustakas, M.; Malea, P.; Zafeirakoglou, A.; Sperdouli, I. Photochemical changes and oxidative damage in the aquatic macrophyte Cymodocea nodosa exposed to paraquat-induced oxidative stress. Pest. Biochem. Physiol. 2016, 126, 28-34. [CrossRef] [PubMed]

65. Sun, H.; Shi, Q.; Zhang, S.-B.; Huang, W. Coordination of cyclic electron flow and water-water cycle facilitates photoprotection under fluctuating light and temperature stress in the epiphytic orchid Dendrobium officinale. Plants 2021, 10, 606. [CrossRef]

66. Sperdouli, I.; Andreadis, S.; Moustaka, J.; Panteris, E.; Tsaballa, A.; Moustakas, M. Changes in light energy utilization in photosystem II and reactive oxygen species generation in potato leaves by the pinworm Tuta absoluta. Molecules 2021, $26,2984$. [CrossRef] [PubMed]

67. Foyer, C.H.; Noctor, G. Redox homeostasis and antioxidant signaling: A metabolic interface between stress perception and physiological responses. Plant Cell 2005, 17, 1866-1875. [CrossRef] [PubMed]

68. Hossain, M.A.; Bhattacharjee, S.; Armin, S.M.; Qian, P.; Xin, W.; Li, H.Y.; Burritt, D.J.; Fujita, M.; Tran, L.S. Hydrogen peroxide priming modulates abiotic oxidative stress tolerance: Insights from ROS detoxification and scavenging. Front. Plant Sci. 2015, 16, 420. [CrossRef]

69. Adamakis, I.D.S.; Sperdouli, I.; Eleftheriou, E.P.; Moustakas, M. Hydrogen peroxide production by the spot-like mode action of bisphenol A. Front. Plant Sci. 2020, 11, 1196. [CrossRef]

70. Adamakis, I.D.S.; Malea, P.; Sperdouli, I.; Panteris, E.; Kokkinidi, D.; Moustakas, M. Evaluation of the spatiotemporal effects of bisphenol A on the leaves of the seagrass Cymodocea nodosa. J. Hazard. Mater. 2021, 404, 124001. [CrossRef]

71. Krieger-Liszkay, A.; Fufezan, C.; Trebst, A. Singlet oxygen production in photosystem II and related protection mechanism. Photosynth. Res. 2008, 98, 551-564. [CrossRef]

72. Dall'Osto, L.; Cazzaniga, S.; Bressan, M.; Paleček, D.; Židek, K.; Niyogi, K.K.; Fleming, G.R.; Zigmantas, D.; Bassi, R. Two mechanisms for dissipation of excess light in monomeric and trimeric light-harvesting complexes. Nat. Plants 2017, $3,17033$. [CrossRef] [PubMed]

73. Moustakas, M.; Bayçu, G.; Gevrek-Kürüm, N.; Moustaka, J.; Csatári, I.; Rognes, S.E. Spatiotemporal heterogeneity of photosystem II function during acclimation to zinc exposure and mineral nutrition changes in the hyperaccumulator Noccaea caerulescens. Environ. Sci. Pollut. Res. 2019, 26, 6613-6624. [CrossRef]

74. Sperdouli, I.; Moustaka, J.; Antonoglou, O.; Adamakis, I.D.S.; Dendrinou-Samara, C.; Moustakas, M. Leaf age dependent effects of foliar-sprayed CuZn nanoparticles on photosynthetic efficiency and ROS generation in Arabidopsis thaliana. Materials 2019, 12, 2498. [CrossRef]

75. Hideg, É.; Spetea, C.; Vass, I. Singlet oxygen production in thylakoid membranes during photoinhibition as detected by EPR spectroscopy. Photosynth. Res. 1994, 39, 191-199. [CrossRef]

76. Triantaphylidès, C.; Havaux, M. Singlet oxygen in plants: Production, detoxification and signaling. Trends Plant Sci. 2009, 14, 219-228. [CrossRef]

77. Telfer, A. Singlet oxygen production by PSII under light stress: Mechanism, detection and the protective role of beta-carotene. Plant Cell Physiol. 2014, 55, 1216-1223. [CrossRef]

78. Qi, M.; Liu, X.; Li, Y.; Song, H.; Yin, Z.; Zhang, F.; He, Q.; Xu, Z.; Zhou, G. Photosynthetic resistance and resilience under drought, flooding and rewatering in maize plants. Photosynth. Res. 2021, 148, 1-15. [CrossRef]

79. Shirao, M.; Kuroki, S.; Kaneko, K.; Kinjo, Y.; Tsuyama, M.; Förster, B.; Takahashi, S.; Badger, M.R. Gymnosperms have increased capacity for electron leakage to oxygen (Mehler and PTOX reactions) in photosynthesis compared with angiosperms. Plant Cell Physiol. 2013, 54, 1152-1163. [CrossRef]

80. Demmig-Adams, B.; Stewart, J.J.; Adams, W.W.A., III. Multiple feedbacks between chloroplast and whole plant in the context of plant adaptation and acclimation to the environment. Philos. Trans. R. Soc. Lond. B Biol. Sci. 2014, 369, 20130244. [CrossRef]

81. Dietz, K.J.J.; Turkan, I.; Krieger-Liszkay, A. Redox- and reactive oxygen species dependent signaling into and out of the photosynthesizing chloroplast. Plant Physiol. 2016, 171, 1541-1550. [CrossRef]

82. Moustaka, J.; Panteris, E.; Adamakis, I.D.S.; Tanou, G.; Giannakoula, A.; Eleftheriou, E.P.; Moustakas, M. High anthocyanin accumulation in poinsettia leaves is accompanied by thylakoid membrane unstacking, acting as a photoprotective mechanism, to prevent ROS formation. Environ. Exp. Bot. 2018, 154, 44-55. [CrossRef]

83. Foyer, C.H.; Noctor, G. Redox regulation in photosynthetic organisms: Signaling, acclimation, and practical implications. Antioxid. Redox Sign. 2009, 11, 861-905. [CrossRef]

84. Czarnocka, W.; Karpiński, S. Friend or foe? Reactive oxygen species production, scavenging and signaling in plant response to environmental stresses. Free Radic. Biol. Med. 2018, 122, 4-20. [CrossRef] 
85. Agathokleous, E.; Kitao, M.; Harayama, H. On the non-monotonic, hermetic photoprotective response of plants to stress. Dose-Response 2019, 17, 1-3. [CrossRef] [PubMed]

86. Stamelou, M.L.; Sperdouli, I.; Pyrri, I.; Adamakis, I.D.S.; Moustakas, M. Hormetic responses of photosystem II in tomato to Botrytis cinerea. Plants 2021, 10, 521. [CrossRef]

87. Bielczynski, L.W.; Łacki, M.K.; Hoefnagels, I.; Gambin, A.; Croce, R. Leaf and plant age affects photosynthetic performance and photoprotective capacity. Plant Physiol. 2017, 175, 1634-1648. [CrossRef]

88. Balakumar, T.; Hani Babu, V.; Paliwal, K. On the interaction of UV-B radiation (280-315 nm) with water stress in crop plants. Physiol. Plant. 1993, 87, 217-222. [CrossRef]

89. Dillenburg, L.R.; Sullivan, J.H.; Teramura, A.H. Leaf expansion and development of photosynthetic capacity and pigments in Liquidambar styraciflua. Am. J. Bot. 1995, 82, 433-440. [CrossRef]

90. Greer, D.H.; Halligan, E.A. Photosynthetic and fluorescence light responses for kiwifruit leaves at different stages of development on vines grown at two different photon flux densities. Aust. J. Plant Physiol. 2001, 28, 373-382. [CrossRef]

91. Sperdouli, I.; Moustakas, M. Differential response of photosystem II photochemistry in young and mature leaves of Arabidopsis thaliana to the onset of drought stress. Acta Physiol. Plant. 2012, 34, 1267-1276. [CrossRef]

92. Jiang, C.D.; Li, P.M.; Gao, H.Y.; Zou, Q.; Jiang, G.M.; Li, L.H. Enhanced photoprotection at the early stages of leaf expansion in field-grown soybean plants. Plant Sci. 2005, 168, 911-919. [CrossRef]

93. Zhang, S.B.; Hao, Y.J.; Deng, Q.L. Photosynthetic induction is slower in young leaves than in mature leaves in a tropical invader, Chromolaena odorata. Photosynthetica 2019, 57, 1044-1052. [CrossRef]

94. Asada, K. Production and scavenging of reactive oxygen species in chloroplasts and their functions. Plant Physiol. 2006, 141, 391-396. [CrossRef]

95. Mittler, R. ROS are good. Trends Plant Sci. 2017, 22, 11-19. [CrossRef]

96. Sun, Z.; Shen, Y.; Niinemets, Ü. Responses of isoprene emission and photochemical efficiency to severe drought combined with prolonged hot weather in hybrid Populus. J. Exp. Bot. 2020, 71, 7364-7381. [CrossRef] [PubMed]

97. Sperdouli, I.; Moustakas, M. Spatio-temporal heterogeneity in Arabidopsis thaliana leaves under drought stress. Plant Biol. 2012, 14, 118-128. [CrossRef]

98. Moustakas, M.; Malea, P.; Haritonidou, K.; Sperdouli, I. Copper bioaccumulation, photosystem II functioning and oxidative stress in the seagrass Cymodocea nodosa exposed to copper oxide nanoparticles. Environ. Sci. Pollut. Res. 2017, 24, 16007-16018. [CrossRef]

99. Gray, G.R.; Savitch, L.V.; Ivanov, A.G.; Huner, N.P.A. Photosystem II excitation pressure and development of resistance to photoinhibition. II. Adjustment of photosynthetic capacity in winter wheat and winter rye. Plant Physiol. 1996, 110, 61-71. [CrossRef]

100. Wilson, K.E.; Ivanov, A.G.; Öquist, G.; Grodzinski, B.; Sarhan, F.; Huner, N.P.A. Energy balance, organellar redox status, and acclimation to environmental stress. Can. J. Bot. 2006, 84, 1355-1370. [CrossRef]

101. Chaerle, L.; Hagenbeek, D.; De Bruyne, E.; Valcke, R.; Van Der Straeten, D. Thermal and chlorophyll-fluorescence imaging distinguish plant-pathogen interactions at an early stage. Plant Cell Physiol. 2004, 45, 887-896. [CrossRef] [PubMed]

102. Moustaka, J.; Meyling, N.V.; Hauser, T.P. Induction of a compensatory photosynthetic response mechanism in tomato leaves upon short time feeding by the chewing insect Spodoptera exigua. Insects 2021, 12, 562. [CrossRef]

103. Moustaka, J.; Tanou, G.; Giannakoula, A.; Panteris, E.; Eleftheriou, E.P.; Moustakas, M. Anthocyanin accumulation in poinsettia leaves and its functional role in photo-oxidative stress. Environ. Exp. Bot. 2020, 175, 104065. [CrossRef]

104. Kalaji, M.H.; Carpentier, R.; Allakhverdiev, S.I.; Bosa, K. Fluorescence parameters as an early indicator of light stress in barley. J. Photochem. Photobiol. B. 2012, 112, 1-6. [CrossRef]

105. Guidi, L.; Calatayud, A. Non-invasive tools to estimate stress-induced changes in photosynthetic performance in plants inhabiting Mediterranean areas. Environ. Exp. Bot. 2014, 103, 42-52. [CrossRef]

106. Gorbe, E.; Calatayud, A. Applications of chlorophyll fluorescence imaging technique in horticultural research: A review. Sci. Hortic. 2012, 138, 24-35. [CrossRef]

107. Guidi, L.; Mori, S.; Degl'Innocenti, E.; Pecchia, S. Effects of ozone exposure or fungal pathogen on white lupin leaves as determined by imaging of chlorophyll a fluorescence. Plant Physiol. Biochem. 2007, 45, 851-857. [CrossRef]

108. Marchetti, C.F.; Ugena, L.; Humplík, J.F.; Polák, M.; Cavar Zeljkovic, S.; Podlešáková, K.; Fürst, T.; De Diego, N.; Spíchal, L. A novel image-based screening method to study water-deficit response and recovery of barley populations using canopy dynamics phenotyping and simple metabolite profiling. Front. Plant Sci. 2019, 10, 1252. [CrossRef]

109. Guo, Y.; Tan, J. Recent advances in the application of chlorophyll a fluorescence from photosystem II. Photochem. Photobiol. 2015, 91, 1-14. [CrossRef]

110. Yao, J.; Sun, D.; Cen, H.; Xu, H.; Weng, H.; Yuan, F.; He, Y. Phenotyping of Arabidopsis drought stress response using kinetic chlorophyll fluorescence and multicolor fluorescence imaging. Front. Plant Sci. 2018, 9, 603. [CrossRef]

111. Bresson, J.; Vasseur, F.; Dauzat, M.; Koch, G.; Granier, C.; Vile, D. Quantifying spatial heterogeneity of chlorophyll fluorescence during plant growth and in response to water stress. Plant Methods 2015, 11, 23. [CrossRef] [PubMed]

112. Bayçu, G.; Moustaka, J.; Gevrek-Kürüm, N.; Moustakas, M. Chlorophyll fluorescence imaging analysis for elucidating the mechanism of photosystem II acclimation to cadmium exposure in the hyperaccumulating plant Noccaea caerulescens. Materials 2018, 11, 2580. [CrossRef] [PubMed] 
113. Moustakas, M.; Hanć, A.; Dobrikova, A.; Sperdouli, I.; Adamakis, I.D.S.; Apostolova, E. Spatial heterogeneity of cadmium effects on Salvia sclarea leaves revealed by chlorophyll fluorescence imaging analysis and laser ablation inductively coupled plasma mass spectrometry. Materials 2019, 12, 2953. [CrossRef] [PubMed]

114. Moustakas, M.; Calatayud, A.; Guidi, L. Chlorophyll fluorescence imaging analysis in biotic and abiotic stress. Front. Plant Sci. 2021, 12, 658500. [CrossRef]

115. Razavi, F.; Pollet, B.; Steppe, K.; Van Labeke, M.-C. Chlorophyll fluorescence as a tool for evaluation of drought stress in strawberry. Photosynthetica 2008, 46, 631-633. [CrossRef]

116. Woolery, P.O.; Schmal, J.L.; Davis, A.S. Evaluation of chlorophyll fluorescence as an indicator of dehydration stress in American chestnut seedlings. Native Plants J. 2010, 11, 27-32. [CrossRef]

117. Antonoglou, O.; Moustaka, J.; Adamakis, I.D.; Sperdouli, I.; Pantazaki, A.; Moustakas, M.; Dendrinou-Samara, C. Nanobrass CuZn nanoparticles as foliar spray non phytotoxic fungicides. ACS Appl. Mater. Interfaces 2018, 10, 4450-4461. [CrossRef]

118. Varela, M.C.; Arslan, I.; Reginato, M.A.; Cenzano, A.M.; Luna, M.V. Phenolic compounds as indicators of drought resistance in shrubs from Patagonian shrublands (Argentina). Plant Physiol. Biochem. 2016, 104, 81-91. [CrossRef]

119. Nassour, R.; Ayash, A.; Al-Tameemi, K. Anthocyanin pigments: Structure and biological importance. J. Chem. Pharm. Sci. 2020, $13,45-57$.

120. Hodges, D.M.; DeLong, J.M.; Forney, C.F.; Prange, R.K. Improving the thiobarbituric acid-reactive-substances assay for estimating lipid peroxidation in plant tissues containing anthocyanin and other interfering compounds. Planta 1999, 207, 604-611. [CrossRef]

121. Havaux, M.; Kloppstech, K. The protective functions of carotenoid and flavonoid pigments against excess visible radiation at chilling temperature investigated in Arabidopsis npq and $t t$ mutants. Planta 2001, 213, 953-966. [CrossRef] [PubMed]

122. Oxborough, K.; Baker, N.R. Resolving chlorophyll a fluorescence images of photosynthetic efficiency into photochemical and non-photochemical components—calculation of $\mathrm{q}_{\mathrm{P}}$ and $F_{v}{ }^{\prime} / F_{m}{ }^{\prime}$ without measuring Fo'. Photosynth. Res. 1997, 54, 135-142. [CrossRef]

123. Kitajima, M.; Butler, W.L. Quenching of chlorophyll fluorescence and primary photochemistry in chloroplasts by dibromothymoquinone. Biochim. Biophys. Acta 1975, 376, 105-115. [CrossRef]

124. Genty, B.; Briantais, J.M.; Baker, N.R. The relationship between the quantum yield of photosynthetic electron transport and quenching of chlorophyll fluorescence. Biochim. Biophys. Acta 1989, 99, 87-92. [CrossRef]

125. Kramer, D.M.; Johnson, G.; Kiirats, O.; Edwards, G.E. Newfluorescence parameters for the determination of $Q_{A}$ redox state and excitation energy fluxes. Photosynth. Res. 2004, 79, 209-218. [CrossRef] [PubMed]

126. Hendrickson, L.; Furbank, R.T.; Chow, W.S. A simple alternative approach to assessing the fate of absorbed light energy using chlorophyll fluorescence. Photosynth. Res. 2004, 82, 73-81. [CrossRef]

127. Bilger, W.; Björkman, O. Role of the xanthophyll cycle in photoprotection elucidated by measurements of light-induced absorbance changes, fluorescence and photosynthesis in leaves of Hedera canariensis. Photosynth. Res. 1990, 25. [CrossRef] [PubMed] 